\title{
In Vitro Control of Uropathogenic Microorganisms with the Ethanolic Extract from the Leaves of Cochlospermum regium (Schrank) Pilger
}

\author{
Danny Ellen Meireles Leme, ${ }^{1}$ Allan Belarmino Rodrigues, ${ }^{1}$ \\ Adriana Araújo de Almeida-Apolonio, ${ }^{2}$ Fabiana Gomes da Silva Dantas, ${ }^{3}$ \\ Melyssa Fernanda Norman Negri, ${ }^{4}$ Terezinha Inez Estivalet Svidzinski, ${ }^{4}$ \\ Jonas da Silva Mota, ${ }^{5}$ Claudia Andrea Lima Cardoso, ${ }^{5}$ and Kelly Mari Pires de Oliveira ${ }^{3,6}$ \\ ${ }^{1}$ Faculty of Exact Sciences and Technology, Federal University of Grande Dourados, Dourados, MS, Brazil \\ ${ }^{2}$ Faculty of Medicine, Federal University of Mato Grosso do Sul, Campo Grande, MS, Brazil \\ ${ }^{3}$ Faculty of Health Sciences, Federal University of Grande Dourados, Dourados, MS, Brazil \\ ${ }^{4}$ Department of Clinical Analysis and Biomedicine, State University of Maringá, Maringá, PR, Brazil \\ ${ }^{5}$ Course of Chemistry, State University of Mato Grosso do Sul, Dourados, MS, Brazil \\ ${ }^{6}$ Faculty of Biological and Environmental Science, Federal University of Grande Dourados, Dourados, MS, Brazil \\ Correspondence should be addressed to Kelly Mari Pires de Oliveira; kellyoliveira@ufgd.edu.br
}

Received 3 August 2017; Revised 3 November 2017; Accepted 9 November 2017; Published 11 December 2017

Academic Editor: Letizia Angiolella

Copyright ( 2017 Danny Ellen Meireles Leme et al. This is an open access article distributed under the Creative Commons Attribution License, which permits unrestricted use, distribution, and reproduction in any medium, provided the original work is properly cited.

\begin{abstract}
The roots of Cochlospermum regium, popularly known as "algodãozinho-do-cerrado," are used for the treatment of genitourinary infections. However, the removal of their subterranean structures results in the death of the plant, and the use of the leaves becomes a viable alternative. Therefore, the antimicrobial activity of Cochlospermum regium leaf's ethanolic extract and its action on the biofilm formation of microorganisms associated with urinary infection were evaluated. The total phenolic compounds, flavoids, and tannins were quantified using the reagents Folin-Ciocalteu, aluminum chloride, and vanillin, respectively. The antimicrobial activity was evaluated by the broth microdilution method and the effect of the extract in the biofilm treatment was measured by the drop plate method. Cytotoxicity was evaluated by the method based on the reduction of MTS and the mutagenicity by the Ames test. The ethanolic extract of $C$. regium leaves presented $87.4 \mathrm{mg} / \mathrm{EQ}$ of flavonoids, $167.2 \mathrm{mg} / \mathrm{EAG}$ of total phenolic compounds, and $21.7 \mathrm{mg} / \mathrm{ECA}$ of condensed tannins. It presented reduction of the biofilm formation for E. coli and C. tropicalis and antimicrobial action of $1 \mathrm{mg} / \mathrm{mL}$ and $0.5 \mathrm{mg} / \mathrm{mL}$, respectively. The extract showed no cytotoxicity and mutagenicity at the concentrations tested. This study demonstrated that $C$. regium leaves are a viable option for the treatment of genitourinary infections and for the species preservation.
\end{abstract}

\section{Introduction}

Urinary tract infection (UTI) is a public health problem that affects millions of people every year [1]. It is defined as the colonization of pathogenic microorganisms that affect the urinary system tissues causing infection [2]. Urinary infection of bacterial origin is most often caused by enteric Gram-negative bacteria, with Escherichia coli being the most predominant microorganism [3, 4]. Opportunistic microorganisms such as yeast are also considered uropathogens, and the genus Candida has been reported as one of the most important [5]. Among yeasts of this genus, Candida tropicalis is among the most isolated ones in patients diagnosed with urinary infection [6].

A serious nosocomial problem currently faced in relation to these microorganisms is the formation of biofilm, which 
is characterized as microbial communities with complex organizational structure that may be present in hospital equipment and instruments causing or aggravating infections $[7,8]$.

Since ancient times, medicinal plants are alternative resources used by the population for therapeutic purposes [9]. It is estimated that approximately $90 \%$ of people have already used natural medicine for the primary relief of some discomfort caused by diseases [10]. The World Health Organization (WHO) [11] encourages research regarding the use of plants, with the aim of ensuring that the therapeutic properties present in these natural products can be applied to prevent/treat diseases without damaging health.

Cochlospermum regium (Schrank) Pilger is a shrub of the family Bixaceae Kunth, popularly known as "algodãozinhodo-campo" or "algodãozinho-do-cerrado" [12]. According to sellers of medicinal herbs, C. regium roots and xylopods are among the most sought-after medicinal plants and are indicated for the therapeutic treatment of uterine, ovarian, and prostate inflammation and infection [13]. In addition to the antimicrobial action, the roots and xylopods also present analgesic, antidematogenic and anti-inflammatory activity $[14,15]$. These biological activities may be related to the presence of phenolic compounds, such as ellagic acid, gallic acid, dihydrokaempferol-3-O- $\beta$-glucopyranoside and dihydrokaempferol-3-O- $\beta$-glucopyranoside and dihydrokaempferol-3-O- $\beta$-( $6^{\prime \prime}$-galloyl)-glucopyranoside, pinoresinol, excel sine, and two triacil benzenes known as Cochlospermines A and B [14]. In relation to the leaves of C. regium, several substances have already been identified and isolated from their essential oil showing the presence of $96.87 \%$ sesquiterpenes, being $18.73 \% \beta$-copaen- $4-\alpha$-ol and $12.67 \%$ of viridiflorol [16]. However, in the literature there are still no reports of antimicrobial activity with $C$. regium leaves.

Much used because of its subterranean parts, C. regium is among the priority species for conservation, due to the fact that the removal of its roots causes the destruction of the bush [17] and, for this reason, the number of researches on the processes of germination and in vitro preservation increases $[18,19]$. In this sense, the use of the leaves has been proposed in order to minimize the impacts on the plant, since previous studies report the presence of the same compounds as in the root. Thus, the aim of this work was to evaluate the antimicrobial activity and action on the biofilm formation of microorganisms associated with urinary infection, from the ethanolic extract of Cochlospermum regium leaves.

\section{Material and Methods}

The leaves of Cochlospermum regium were collected at Santa Madalena Farm (S $22^{\circ} 13^{\prime} 41.8^{\prime \prime} / \mathrm{W} 054^{\circ} 49^{\prime} 58.4^{\prime \prime}$ ), Dourados, MS. The exsiccate was identified by Dr. Zefa Valdivina Pereira and deposited (DDMS 5001) in the Herbarium of the Faculdade de Ciências Biológicas e Ambientais from Universidade Federal da Grande Dourados, Dourados, MS, Brazil.

The dry and crushed vegetable material (200 g) was mixed in $1000 \mathrm{~mL}$ of $95 \%$ absolute ethyl alcohol (Dynamics Contemporary Chemistry Ltd., Diadema, BRA) and maintained at $25^{\circ} \mathrm{C}$ for $72 \mathrm{~h}$ with shaking about every $12 \mathrm{~h}$. The solutions were filtered and evaporated (Rotaevapor R-215) at $35^{\circ} \mathrm{C}$ until complete solvent volatilization. The obtained plant extract was lyophilized (E-C MicroModulyo coupled to valuPump VLP80 Savant vacuum pump).

\subsection{Quantification of Phenolic Compounds of the Ethanolic} Extract of Cochlospermum Regium Leaves. Tests were performed to track the following classes of compounds: organic acids [20], steroids and triterpenes [21], flavonoids [21], total phenolic compounds, condensed tannins [21], and alkaloids $[21,22]$. Among these classes flavonoids, total phenolic compounds, and condensed tannins were quantified.

The concentration of flavonoids was determined using the method described by Lin and Tang [23] and the results were expressed as milligram equivalents of quercetin (mg/EQ) per gram of the ethanolic extract. The concentration of total phenolic compounds was determined by the method of Djeridane et al. [24] and the results were expressed as milligram equivalents of gallic acid (mg/EGA) per gram of ethanolic extract. The concentration of condensed tannins was determined by the method proposed by Broadhurst and Jones [25] and adapted by Agostini-costa et al. [26]. The results were expressed as milligram equivalent of catechin (mg/ ECA) per gram of extract.

2.2. Minimal Inhibitory Concentration and Minimum Bactericidal/Fungicidal Concentration. The Minimal Inhibitory Concentration (MIC) of the extract was determined by the broth microdilution method, according to the guidelines of the Clinical and Laboratory Standards Institute [27, 28], with adaptations for natural products. Microorganisms from the American Type Culture Collection (ATCC, Rockville, MD, USA), Escherichia coli (ATCC 25922) and Candida tropicalis (ATCC 750), and three clinical isolates from each of these species were tested (Laboratory of Applied Microbiology, University of Grande Dourados, Dourados).

Bacteria were cultured on Tryptone Soy agar (TSA, Himedia, Mumbai, India) at $37^{\circ} \mathrm{C}$ for $24 \mathrm{~h}$ and the inoculum concentration was adjusted to $1.5 \times 10^{8} \mathrm{CFU} / \mathrm{mL}$ using a wavelength of $625 \mathrm{~nm}$ in a spectrophotometer (Visible Digital Microprocessor Q898DRM-QUIMIS ISO 8001). The yeasts were cultured on Sabouraud Dextrose agar (SDA, Himedia, Mumbai, IND) at $35^{\circ} \mathrm{C}$ for $48 \mathrm{~h}$ and the inoculum concentration adjusted to $2.5 \times 10^{6} \mathrm{CFU} / \mathrm{mL}$ at the $530 \mathrm{~nm}$ wavelength.

The extract was dissolved in dimethyl sulfoxide (DMSO, Sigma-Aldrich) and subjected to successive dilutions $(1: 2)$ in 96 well plates with Müeller Hinton broth (MHB, Himedia, Mumbai, India) for bacteria and RPMI 1640 broth (SigmaAldrich, São Paulo, Brazil) for the yeasts, obtaining concentrations from $1 \mathrm{mg} / \mathrm{mL}$ to $0.0019 \mathrm{mg} / \mathrm{mL}$. The antibiotic ampicillin (AMP, Sigma-Aldrich, São Paulo, Brazil) and antifungal fluconazole (FLU, Sigma-Aldrich, São Paulo, BRA) were used to control the assay.

For bacteria, in addition to visual reading, the minimum inhibitory concentration (MIC) was determined by adding to the wells $50 \mu \mathrm{L}$ of $0.1 \%$ solution of triphenyltetrazolium chloride (TTC, Vetec, Sigma-Aldrich, São Paulo, Brazil) for $30 \mathrm{~min}$. The yeast reading was performed visually. CIM was considered as the lowest concentration of the extract in which 
the microorganisms did not show visible growth [29]. The test was performed in duplicate at three different times.

To determine the minimum bactericidal concentration (MBC) and minimum fungicidal concentration (MFC), a $10 \mu \mathrm{L}$ aliquot of all wells from the microplate was removed and plated on a Müeller Hinton agar (Himedia, Mumbai, India) for bacteria and Sabouraud Dextrose agar (SDA, Himedia, Mumbai, India) for yeast. MBC and MFC were defined as the lowest concentration in which there was no colony growth [30].

Microbial activity was determined according to the parameters established by Kuete [31], significant activity $(\mathrm{MIC}<0.1 \mathrm{mg} / \mathrm{mL})$, moderate activity $(0.1 \mathrm{mg} / \mathrm{mL} \leq \mathrm{MIC} \leq$ $0.625 \mathrm{mg} / \mathrm{mL}$ ), and low activity (MIC $>0.625 \mathrm{mg} / \mathrm{mL}$ ).

2.3. Antimicrobial Activity in Biofilm. The microorganisms Escherichia coli (ATCC 25922) and Candida tropicalis (ATCC 750) were tested.

To prepare the inoculum, E. coli was resuspended in $25 \mathrm{~mL}$ of Tryptone Soy Broth (TSB, Himedia, Mumbai, India) at $37^{\circ} \mathrm{C}$ and C. tropicalis in Sabouraud Dextrose broth (SDB, Himedia, Mumbai, India) at $35^{\circ} \mathrm{C}$; both resuspensions were kept overnight under $80 \mathrm{rpm}$ orbital shaking. After incubation, the cells were washed three times with $25 \mathrm{ml}$ of $0.1 \mathrm{M}$ phosphate buffered saline (PBS) $\mathrm{pH} 7.0$ and centrifuged at $10,000 \mathrm{~g}$ for $5 \mathrm{~min}$ at $4^{\circ} \mathrm{C}$. Subsequently, they were adjusted in the Neubauer counting chamber at a concentration of 2.48 $\times 10^{8} \mathrm{CFU} / \mathrm{mL}$ of bacteria and $5 \times 10^{5} \mathrm{CFU} / \mathrm{mL}$ of yeast.

To determine the efficacy of the extract in the treatment of biofilm, the assays were carried out in 96-well flat bottom microplates (Nunclon, Delta, Nunc A/S, Roskilde, Denmark), according to the methodology proposed by Costa et al. [32], with some modifications. For biofilm formation, $200 \mu \mathrm{L}$ of preadjusted inoculum was added to the microplate wells and incubated at $37^{\circ} \mathrm{C}$ for $24 \mathrm{~h}$ for bacteria and at $35^{\circ} \mathrm{C}$ for $48 \mathrm{~h}$ for yeast under orbital shaking at $80 \mathrm{rpm}$.

After biofilm formation, the wells were washed three times with $200 \mu \mathrm{l}$ of PBS and then treated with different concentrations of the extract $(16 \mathrm{mg} / \mathrm{mL}, 8 \mathrm{mg} / \mathrm{mL}, 4 \mathrm{mg} / \mathrm{mL}$, $2 \mathrm{mg} / \mathrm{mL}$, and $1 \mathrm{mg} / \mathrm{mL}$ ). After this step, the wells were aspirated and washed three times with $200 \mu \mathrm{l}$ of PBS for removal of the poorly adhered cells. For quantification of the biofilm formed, the wells were scraped and the obtained suspensions were serially diluted with 10 replicates for each concentration and plated by the Drop plate method in Müeller Hinton agar (MHA, Himedia, Mumbai, India) for the bacterium and Sabouraud Dextrose agar (SDA, Himedia, Mumbai, India) for yeast.

The assays were performed in triplicate and, as control of biofilm formation, the inoculum and its corresponding culture medium were added. Subsequently, the colony forming units $(\mathrm{CFU})$ were counted and the results were converted to $\log 10$.

2.4. Cytotoxicity Assay. The cytotoxicity of the ethanolic extract from the leaves of $C$. regium was evaluated using HeLa cell lines (Henrietta Lacks, cervical adenocarcinoma cell line) and VERO (lineage established from African green monkey kidney cells, Cercopithecus aethiops). HeLa cells were cultured in Dulbecco's Modified Eagle's medium (DMEM, Gibco, Waltham, USA) with $10 \%$ fetal bovine serum (FBS, Gibco, Waltham, USA) and VERO cells in RPMI 1640 medium (Sigma-Aldrich, USA). Cells set at $2 \times 10^{5}$ cells $/ \mathrm{mL}$ were added to the 96-well microplates (Kasvi, Curitiba, Brazil) and incubated at $37^{\circ} \mathrm{C}$ under $5 \% \mathrm{CO}_{2}$ for $24 \mathrm{~h}$. After the incubation period, the adhered cells were washed and treated with different concentrations of the extract $(0.5 \mathrm{mg} / \mathrm{mL}, 0.15 \mathrm{mg} /$ $\mathrm{mL}$, and $0.05 \mathrm{mg} / \mathrm{mL}$ ) and incubated under the same conditions. For growth control (white) the culture medium and the cell suspension were used.

Cell viability was evaluated based on the reduction of MTS (3-[4,5-dimethylthiazol-2-yl]-5-[3-carboxymethoxyphenyl]-2-[4-sulfophenyl]-2H-tetrazolium) (Promega, Madison Charter Township, USA). After $3 \mathrm{~h}$ of incubation at $37^{\circ} \mathrm{C}$, the formazan absorbance was measured at $490 \mathrm{~nm}$ wavelength, using an ASYS microplate reader (Biochrom, Holliston, USA). Optical density (OD) values were converted to percent cell viability by dividing the absorbance value of the sample by the absorbance of the blank and multiplying the result by 100 . The assays were performed in triplicate at three different times $[33,34]$.

2.5. Mutagenicity Assay. The mutagenic potential of the ethanolic extract of $C$. regium leaves was evaluated by the microsuspension method developed by Maron and Ames [35] with some modifications proposed by Kado et al. [36]. The assays were performed with strains of Salmonella Typhimurium TA97a, TA98, TA100, and TA102 in the presence and absence of metabolic activation.

The overnight bacterial suspension was concentrated at 2 $\times 10^{9}$ bacteria/mL by centrifugation and then resuspended in sodium phosphate buffer solution ( $\mathrm{pH} 7.4,0.2 \mathrm{mM}$ ). $50 \mu \mathrm{L}$ of adjusted inoculum was added to the tubes containing $50 \mu \mathrm{L}$ of phosphate buffer solution ( $\mathrm{pH} 7.4,0.2 \mathrm{mM}$ ) or $\mathrm{S} 9$ mixture (Molotoxic Molecular Toxicology Inc., USA) and $5 \mu \mathrm{L}$ of the different concentrations of the extract $(2 \mathrm{mg} / \mathrm{mL}, 1 \mathrm{mg} / \mathrm{mL}$, $0.5 \mathrm{mg} / \mathrm{mL}, 0.25 \mathrm{mg} / \mathrm{mL}$, and $0.125 \mathrm{mg} / \mathrm{mL}$ ). The tubes were preincubated for $90 \mathrm{~min}$ at $37^{\circ} \mathrm{C}$.

Following this time, $2 \mathrm{~mL}$ of top agar $[0.6 \%(\mathrm{w} / \mathrm{v})$ sodium chloride, $0.6 \%(\mathrm{w} / \mathrm{v})$ agar-agar (Difco, USA), $0.5 \mathrm{mM} \mathrm{D-}$ biotin (Sigma-Aldrich, USA), 0.5\% L-histidine (w/v) (SigmaAldrich, USA)] was added to the solution and the tubes were homogenized and poured into glycated minimum agar (GMA) plates $[1.5 \%(\mathrm{w} / \mathrm{v})$ agar-agar (Difco, USA), 20\% glucose solution (w/v) (Vetec, Brazil), and 2\% (v/v) VogelBonner solution]. The number of revertant colonies per his+ plate was measured after $66 \mathrm{~h}$ at $37^{\circ} \mathrm{C}$. The assays were performed in triplicate.

The positive controls used in the assays without metabolic activation were 4-nitro-o-phenylenediamine (NPD, SigmaAldrich, USA) $(0.5 \mu \mathrm{g} /$ plate) for TA97a and TA 98 and sodium azide (Sigma-Aldrich, USA) $(2.5 \mu \mathrm{g} /$ plate) for TA100 and mitomycin C (Sigma-Aldrich, USA) $(0.5 \mu \mathrm{g} /$ plate) for TA102. In the metabolic activation assays the 2-aminoanthracene compound (2-AA, Sigma-Aldrich, USA) $(0.625 \mu \mathrm{g} /$ plate) was used for all strains. Negative controls were performed with the sample solvent, DMSO ( $5 \mu \mathrm{L} /$ plate). 
TABLE 1: Minimum inhibitory concentration, minimal bactericidal concentration, and minimum fungicidal concentration in $\mathrm{mg} / \mathrm{mL}$ of the ethanolic extract of Cochlospermum regium leaves against microorganisms associated with urinary infection.

\begin{tabular}{|c|c|c|c|c|c|}
\hline Microorganisms & MIC & $\mathrm{MBC}$ & MFC & AMP & FLU \\
\hline Escherichia coli (ATCC 25922) & 1 & - & $*$ & 0.032 & $*$ \\
\hline Escherichia coli (1) & 1 & - & * & $>0.016$ & * \\
\hline Escherichia coli (2) & 1 & - & * & $>0.016$ & * \\
\hline Escherichia coli $(3)$ & 1 & - & $*$ & $>0.016$ & $*$ \\
\hline Candida tropicalis (ATCC 750) & 0.5 & * & - & $*$ & 0.001 \\
\hline Candida tropicalis (1) & 0.5 & * & - & * & 0.001 \\
\hline Candida tropicalis (2) & 0.5 & * & - & * & 0.001 \\
\hline Candida tropicalis (3) & 0.5 & $*$ & 0.5 & $*$ & 0.001 \\
\hline
\end{tabular}

MIC: minimum inhibitory concentration; MBC: minimum bactericidal concentration; MFC: minimum fungicide concentration; (-): absence of antimicrobial activity; (*): not tested; AMP: ampicillin; FLU: fluconazole.
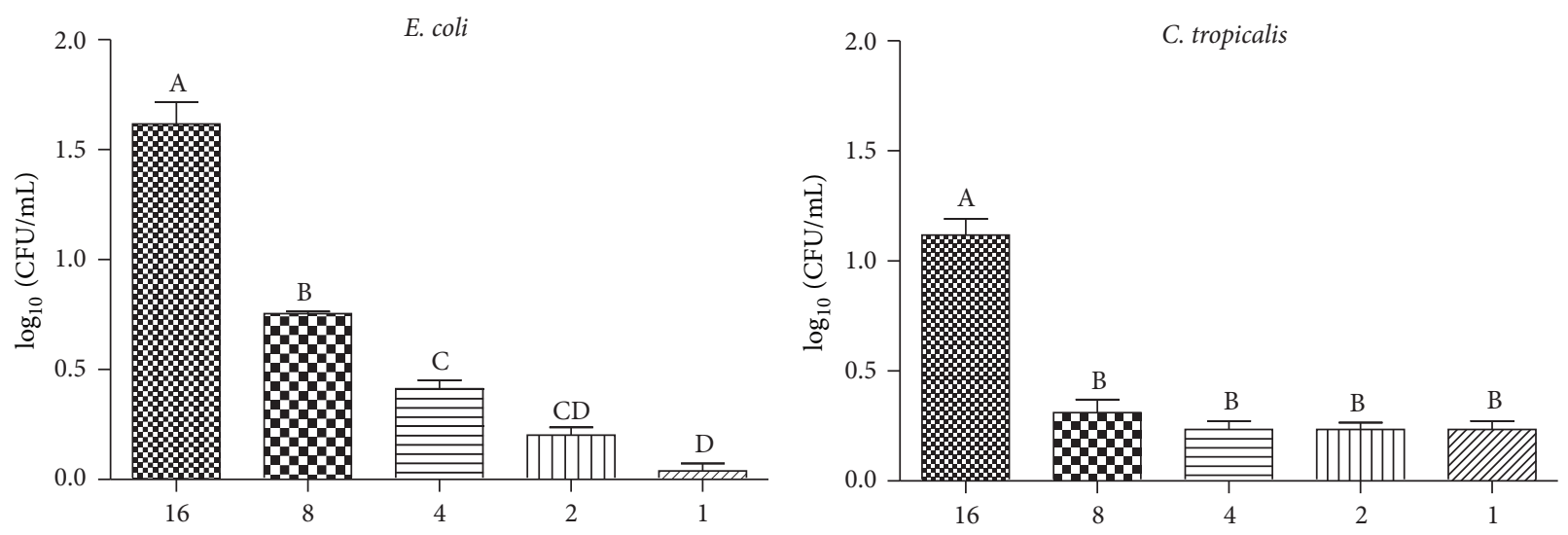

FIGURE 1: Reduction of CFU/mL (log10) number of Escherichia coli and Candida tropicalis biofilm treated with different concentrations of the ethanolic extract of Cochlospermum regium leaves in $\mathrm{mg} / \mathrm{mL}$. Different letters represent statistically significant differences found $(p<0.05)$.

2.6. Statistical Analysis. Data on inhibition of preformed biofilm and cytotoxicity were analysed using GraphPad Prism 5.0 statistical software (GraphPad Software, Inc., USA). Ames test data were analyzed without the statistical program Salanal (US Environmental Protection Agency, Monitoring Systems Laboratory, USA, version 1.0, Research Research Triangle Institute, RTP, USA).

\section{Results}

The ethanolic extract of the leaves (EEF) of C. regium indicated the presence of organic acids, steroids and triterpenes, flavonoids, total phenolic compounds and condensed tannins, and absence of alkaloids. A total of $87.4 \pm 0.9 \mathrm{mg} / \mathrm{EQ}$ of flavonoids, $167.2 \pm 2.7 \mathrm{mg} / \mathrm{EAG}$ of total phenolic compounds, and $21.7 \pm 0.1 \mathrm{mg} /$ ECA of condensed tannins were quantified.

It presented antimicrobial activity against microorganisms associated with urinary infection. The ethanolic extract of the leaves of C. regium presented a low antimicrobial activity $(1 \mathrm{mg} / \mathrm{mL})$ for $E$. coli and a moderate activity $(0.5 \mathrm{mg} / \mathrm{mL})$ C. tropicalis (Table 1 ).

At the concentrations of $16 \mathrm{mg} / \mathrm{mL}$ and $8 \mathrm{mg} / \mathrm{mL}$, the $C$. regium $\mathrm{EEF}$ reduced the preformed $E$. coli biofilm and at the concentration of $16 \mathrm{mg} / \mathrm{mL}$ the C. tropicalis biofilm was also reduced (Figure 1 ).
The C. regium EEF showed $60 \%$ of cell viability for $\mathrm{HeLa}$ and $92 \%$ for VERO at a concentration of $0.50 \mathrm{mg} / \mathrm{mL}$ (Figure 2).

The EEF of $C$. regium did not present a mutagenic potential, in the absence and presence of the metabolic activation system (S9), at all tested concentrations and for all evaluated strains of Salmonella Typhimurium (Tables 2 and 3).

\section{Discussion}

The EEF of $C$. regium presented organic acids, steroids and triterpenes, flavonoids, total phenolic compounds, condensed tannins, and absence of alkaloids. These results corroborate with Vasconcelos Filho et al. [37] in a study carried out with the leaves, stem, and root of $C$. regium and report that phenolic compounds are among the most commonly found compounds in these parts of the plant, among them tannins and absence of alkaloids in their leaves.

According to Goulas et al. [38], phytochemicals may exhibit antimicrobial activity. Authors report that the terpenes and tannins found in the leaves of $C$. regium have activity against fungi and bacteria $[39,40]$. In addition, the EEF of $C$. regium also presents as major compounds the phenolic compounds and flavonoids, which have been reported in the literature as antimicrobials, being responsible for the rupture 

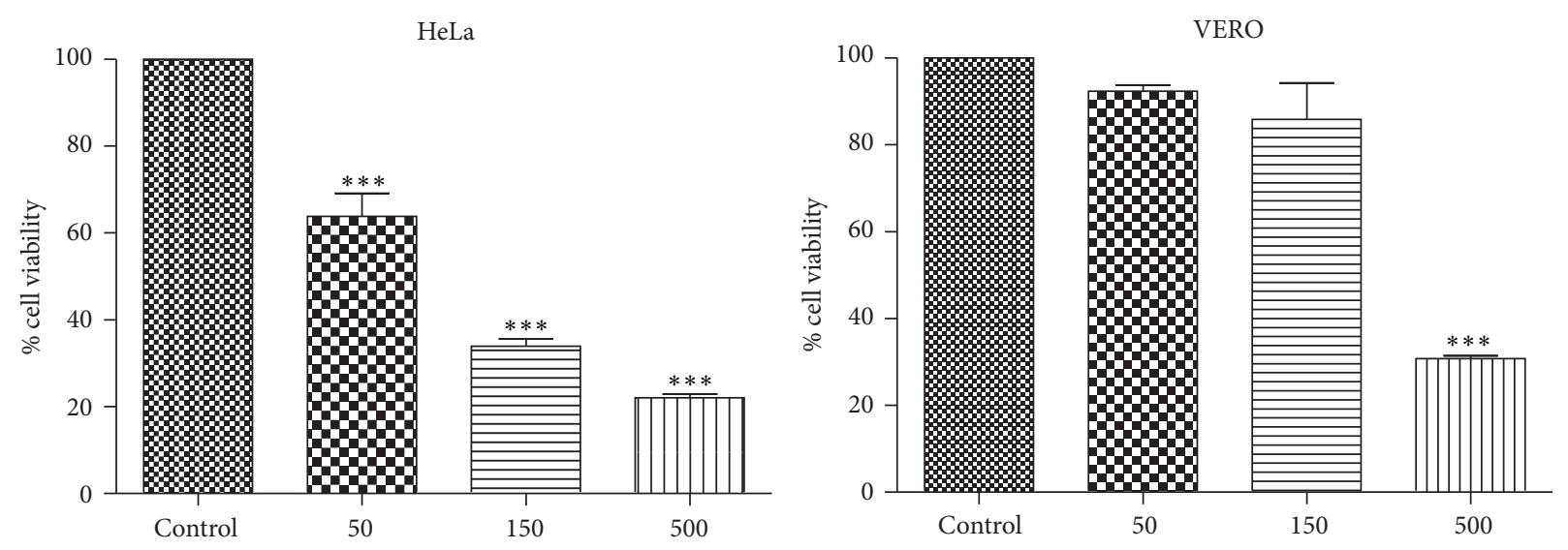

FIgURE 2: Cell viability of HeLa and VERO cells treated with ethanolic extract of $C$. regium for 24 hours. ${ }^{* * *} P<0.001$ (ANOVA).

TABLE 2: Mutagenic potential expressed by mean and standard deviation of revertant colonies per plate and mutagenicity index in the absence of metabolic activation of the ethanolic extract of Cochlospermum regium leaves.

\begin{tabular}{|c|c|c|c|c|c|c|c|c|}
\hline \multirow{2}{*}{$\begin{array}{l}\text { Concentration } \\
\text { (mg/plate) }\end{array}$} & \multicolumn{2}{|c|}{ TA97a } & \multicolumn{2}{|c|}{ TA98 } & \multicolumn{2}{|c|}{ TA100 } & \multicolumn{2}{|c|}{ TA102 } \\
\hline & $\mathrm{Mea} / \mathrm{SD}$ & MI & $\mathrm{Mea} / \mathrm{SD}$ & MI & Mea/SD & MI & $\mathrm{Mea} / \mathrm{SD}$ & MI \\
\hline 0.0 & $117 \pm 9$ & 1 & $45 \pm 9$ & 1 & $164 \pm 15$ & 1 & $364 \pm 35$ & 1 \\
\hline 0.125 & $99 \pm 21$ & 0.84 & $32 \pm 1$ & 0.70 & $87 \pm 8$ & 0.53 & $402 \pm 86$ & 1.10 \\
\hline 0.25 & $112 \pm 12$ & 0.95 & $33 \pm 3$ & 0.72 & $113 \pm 37$ & 0.69 & $442 \pm 13$ & 1.21 \\
\hline 0.5 & $138 \pm 10$ & 1.18 & $26 \pm 1$ & 0.52 & $89 \pm 8$ & 0.54 & $360 \pm 19$ & 0.98 \\
\hline 1 & $107 \pm 13$ & 0.91 & $26 \pm 1$ & 0.57 & $116 \pm 34$ & 0.70 & $372 \pm 29$ & 1.01 \\
\hline 2 & $133 \pm 25$ & 1.14 & $26 \pm 1$ & 0.57 & $85 \pm 34$ & 0.52 & $432 \pm 14^{*}$ & 1.18 \\
\hline
\end{tabular}

Mean/SD: mean of revertant colonies and standard deviation; MI: mutagenicity index; 0.0: negative control (dimethyl sulfoxide, DMSO). ${ }^{*} P<0.05$ (ANOVA).

TABLE 3: Mutagenic potential expressed by the mean and standard deviation of revertant colonies per plate and mutagenicity index in the presence of metabolic activation of Cochlospermum regium leaves ethanolic extract.

\begin{tabular}{|c|c|c|c|c|c|c|c|c|}
\hline \multirow{2}{*}{$\begin{array}{l}\text { Concentration } \\
\text { (mg/plate) }\end{array}$} & \multicolumn{2}{|c|}{ TA97a } & \multicolumn{2}{|c|}{ TA98 } & \multicolumn{2}{|c|}{ TA100 } & \multicolumn{2}{|c|}{ TA102 } \\
\hline & $\mathrm{Mea} / \mathrm{SD}$ & MI & Mea/SD & MI & Mea/SD & MI & Mea/SD & MI \\
\hline 0.0 & $139 \pm 8$ & 1 & $22 \pm 5$ & 1 & $142 \pm 5$ & 1 & $398 \pm 9$ & 1 \\
\hline 0.125 & $155 \pm 10$ & 1.11 & $37 \pm 6$ & 1.67 & $117 \pm 22$ & 0.82 & $400 \pm 17$ & 1.00 \\
\hline 0.25 & $145 \pm 7$ & 1.03 & $29 \pm 13$ & 1.31 & $134 \pm 38$ & 0.94 & $437 \pm 18$ & 1.09 \\
\hline 0.5 & $141 \pm 12$ & 1.01 & $31 \pm 3$ & 1.41 & $182 \pm 20$ & 1.28 & $509 \pm 13$ & 1.27 \\
\hline 1 & $138 \pm 8$ & 0.99 & $28 \pm 6$ & 1.28 & $237 \pm 16$ & 1.66 & $420 \pm 20$ & 1.05 \\
\hline 2 & $131 \pm 13$ & 0.93 & $30 \pm 7$ & 1.35 & $237 \pm 15^{* *}$ & 1.66 & $528 \pm 4$ & 1.32 \\
\hline
\end{tabular}

Mea/SD: mean of revertant colonies and standard deviation; MI: mutagenicity index; 0.0 : negative control (dimethyl sulfoxide, DMSO). ${ }^{* *} P<0.01$ (ANOVA).

of the cell membrane of microorganisms and inhibition of nucleic acid synthesis and energetic metabolism [41, 42]. The leaves of $C$. regium presented an antimicrobial action against E. coli, establishing a correlation with the popular use, since this bacterium is responsible for $80-90 \%$ of cases of urinary infection [43]. Another species of the genus Cochlospermum [44] has also been associated with activity against E. coli, reiterating that this genus has antimicrobial properties.

For Candida tropicalis, the leaf extract presented antifungal action at the concentration of $0.5 \mathrm{mg} / \mathrm{mL}$; this data is in agreement with the results of Inácio et al. [45], who demonstrated antifungal action of the C. regium root, this way, indicating that the leaves can be used in substitution to the popular use of the roots helping in the preservation of this species. Rodrigues and de Carvalho [46] report that medicinal species which have the highest risk of extinction are those whose parts used for the preparation of the medicines are roots, stem, or bark of the stem.

Candida is a genus of yeast fungi, which are present in the mucosa, skin, and gastrointestinal tract and make up the vaginal and urethra microbiota. They are considered commensal and opportunistic, and if there is an imbalance due to low immunity, they may prevail the microbiota and become pathogenic [8]. Authors report that Candida tropicalis is 
among the most isolated microorganisms in patients with urinary tract infection [6].

The C. regium EEF reduced the biofilm formed by $E$. coli and C. tropicalis. Adhesion and biofilm formation are virulence factors that promote the increase of antimicrobial resistance and the permanence of these microorganisms in the genitourinary tract. The reduction of the formed biofilm is relevant data, since, when adhered, these microorganisms become less susceptible to the antimicrobial activity.

The use of medicinal plants in the treatment of diseases requires information that ensures absence of toxicity [47]. The C. regium EEF did not show cytotoxicity against VERO cells and it evidenced a potential antiproliferative activity against HeLa cells. Another study has also shown absence of cytotoxicity in C. regium [48].

The C. regium EEF did not show mutagenicity by the Ames test. The assay was performed in the presence and absence of S9 microsomal fraction which simulates an exogenous metabolization process similar to the hepatic metabolism. The sample is considered mutagenic when at least one of the strains has a mutagenicity index greater than or equal to 2 and a dose response relationship between the concentrations tested [49]. Nunes and de Carvalho [50] evaluated the mutagenic potential of the C. regium root extract with Drosophila melanogaster germ cells and found that the extract also does not present mutagenicity by this model.

\section{Conclusion}

The study showed that the Cochlospermum regium EEF showed antimicrobial activity and reduction of biofilm formation in relation to uropathogens, such as Escherichia coli and Candida tropicalis; in addition, it does not present cytotoxicity and mutagenicity by the evaluated tests and concentrations. In this way, the present study enables the use of the leaves, since its use minimizes the impacts caused by the removal of roots and Xylopodia.

\section{Conflicts of Interest}

The authors declare that they have no conflicts of interest.

\section{Acknowledgments}

This work was funded by Coordenação de Aperfeiçoamento de Pessoal de Nível Superior (CAPES), Conselho Nacional de Desenvolvimento Científico e Tecnológico (CNPq), Fundação de Apoio ao Desenvolvimento do Ensino, Ciência e Tecnologia do Estado de Mato Grosso do Sul (FUNDECT), Programa de Pesquisa para o SUS (PPSUS), and Universidade Federal da Grande Dourados (UFGD).

\section{References}

[1] I. Alshami and A. E. Alharbi, "Antimicrobial activity of hibiscus sabdariffa extract against uropathogenic strains isolated from recurrent urinary tract infections," Asian Pacific Journal of Tropical Disease, vol. 4, no. 4, pp. 317-322, 2014.
[2] K. W. Yun, H. Y. Kim, H. K. Park, W. Kim, and I. S. Lim, "Virulence factors of uropathogenic Escherichia coli of urinary tract infections and asymptomatic bacteriuria in children," Journal of Microbiology, Immunology and Infection, vol. 47, no. 6, pp. 455-461, 2014.

[3] A. Braoios, T. F. Turatti, L. C. Meredija, T. R. Campos, and F. H. Denadai, "Infecções do trato urinário em pacientes não hospitalizados: etiologia e padrão de resistência aos antimicrobianos," Jornal Brasileiro de Nefrologia, vol. 45, no. 6, 2009.

[4] M. Mamani, N. Nobari, M. Y. Alikhani, and J. Poorolajal, "Antibacterial susceptibility of Escherichia coli among outpatients with community-acquired urinary tract infection in Hamadan, Iran," Journal of Global Antimicrobial Resistance, vol. 3, no. 1, pp. 40-43, 2015.

[5] F. Q. B. Alenzi, "Virulence factors of Candida species isolated from patients with urinary tract infection and obstructive uropathy," Pakistan Journal of Medical Sciences, vol. 32, no. 1, pp. 143-146, 2016.

[6] I. Maldonado, A. Arechavala, L. Guelfand, S. Relloso, and C. Garbasz, "Infecciones urinarias nosocomiales por levaduras. estudio multicéntrico de 14 hospitales de la red de micología de la Ciudad Autónoma de Buenos Aires," Revista Iberoamericana de Micología, vol. 33, no. 2, pp. 104-109, 2016.

[7] M. S. Rishpana and J. S. Kabbin, "Candiduria in catheter associated urinary tract infection with special reference to biofilm production," Journal of Clinical and Diagnostic Research, vol. 9, no. 10, pp. DC11-DC13, 2015.

[8] J. C. O. Sardi, L. Scorzoni, T. Bernardi, A. M. Fusco-Almeida, and M. J. S. Mendes Giannini, "Candida species: current epidemiology, pathogenicity, biofilm formation, natural antifungal products and new therapeutic options," Journal of Medical Microbiology, vol. 62, no. 1, pp. 10-24, 2013.

[9] R. C. Dutra, M. M. Campos, A. R. S. Santos, and J. B. Calixto, "Medicinal plants in Brazil: Pharmacological studies, drug discovery, challenges and perspectives," Pharmacological Research, vol. 112, pp. 4-29, 2016.

[10] V. F. Da Veiga, "Estudo do consumo de plantas medicinais na Região Centro-Norte do Estado do Rio de Janeiro: aceitação pelos profissionais de saúde e modo de uso pela população," Revista Brasileira de Farmacognosia, vol. 18, no. 2, pp. 308-313, 2008.

[11] Organização Mundial da Saúde (OMS), WHO Traditional Medicine Strategy, Organização Mundial da Saúde (OMS), Geneva, Switzerland, 2013.

[12] P. F. Batista, A. C. Costa, C. A. Megguer, J. da Silva Lima, and J. de Fátima Sales, "Overcoming dormancy and characterization of germination in Cerrado 'algodãozinho' seeds treated with dimethyl sulphoxide," South African Journal of Botany, vol. 92, pp. 89-93, 2014.

[13] G. Nunes, M. d. Silva, U. Resende, and J. d. Siqueira, "Plantas medicinais comercializadas por raizeiros no centro de campo grande, mato grosso do sul," Revista Brasileira de Farmacognosia, vol. 13, no. 2, 2003.

[14] S. Solon, C. A. Carollo, L. F. G. Brandão et al., "Phenolic derivatives and other chemical compounds from," Química Nova, vol. 35, no. 6, pp. 1169-1172, 2012.

[15] F. L. B. Mügge, J. Paula-Souza, J. C. Melo, and M. G. L. Brandão, "Native plant species with economic value from minas gerais and goiás: a discussion on the currentness of the data recovered by the French naturalist auguste de saint-hilaire," Horticultura Brasileira, vol. 34, no. 4, pp. 455-462, 2016. 
[16] M. C. Inácio, T. A. Paz, B. W. Bertoni, M. A. R. Vieira, M. O. M. Marques, and A. M. S. Pereira, "Histochemical investigation of cochlospermum regium (Schrank) Pilg. leaves and chemical composition of its essential oil," Natural Product Research (Formerly Natural Product Letters), vol. 28, no. 10, pp. 727-731, 2014.

[17] C. Bratti, M. C. Vieira, N. A. H. Zárate, A. P. A. Oliveira, B. G. Marafiga, and S. S. L. Fernandes, "Inventory of native medicinal plants on a farm in Dourados- MS," Revista Brasileira de Plantas Medicinais, vol. 15, no. 1, pp. 675-683, 2014.

[18] M. F. B. Coelho, D. M. Sales, and M. C. F. Albuquerque, "Germinação e emergência de Cochlospermumregium (Schrank) Pilg. em diferentes substratos," Revista Brasileira de Plantas Medicinais, vol. 10, no. 4, pp. 90-96, 2008.

[19] M. C. Inácio, B. W. Bertoni, S. de, C. França, and A. M. S. Pereira, "In vitro conservation and low cost micropropagation of cochlospermumregium (Mart. Ex. Schrank)," Journal of Medicinal Plants Research, vol. 5, no. 20, pp. 4999-5007, 2011.

[20] E. Merck, "Reactivos de coloración para cromatografia en capa fina y en papel," Darmstaadt: Merck, p. 76, 1980.

[21] M. E. Wall, M. M. Krider, C. F. Krewson et al., "Steroidal sapogenins. VII. Survey of plants for steroidal sapogenins and other constituents," Journal of the American Pharmaceutical Association, vol. 43, no. 1, pp. 1-7, 1954.

[22] A. F. Costa, Farmacognosia, vol. 3, Lisboa, Portugal, 3 edition, 1982.

[23] J.-Y. Lin and C.-Y. Tang, "Determination of total phenolic and flavonoid contents in selected fruits and vegetables, as well as their stimulatory effects on mouse splenocyte proliferation," Food Chemistry, vol. 101, no. 1, pp. 140-147, 2006.

[24] A. Djeridane, M. Yousfi, B. Nadjemi, D. Boutassouna, P. Stocker, and N. Vidal, "Antioxidant activity of some Algerian medicinal plants extracts containing phenolic compounds," Food Chemistry, vol. 97, no. 4, pp. 654-660, 2006.

[25] R. B. Broadhurst and W. T. Jones, "Analysis of condensed tannins using acidified vanillin," Journal of the Science of Food and Agriculture, vol. 29, no. 9, pp. 788-794, 1978.

[26] T. D. Agostini-costa, D. D. Garriti, L. Lima, S. Freire, F. A. Abreu, and T. Feitosa, "Avaliação de metodologias para determinação de taninos no suco de caju," Boletim do Centro de Pesquisa de Processamento de Alimentos, vol. 17, no. 2, pp. 167-176, 1999.

[27] Clinical and Laboratory Standards Institute, Reference Method for Broth Dilution Antifungal Susceptibility Testing of Yeasts: Approved Standard, CLSI document M100-S17, Clinical and Laboratory Standards Institute, Wayne, Pa, USA, 3rd edition, 2008.

[28] Clinical and Laboratory Standards Institute, Methods for Dilution Antimicrobial Susceptibility Tests for Bacteria That Grow Aerobically; Approved Standard, CLSI document M100-S17, Clinical and Laboratory Standards Institute, Wayne, Pa, USA, 9th edition, 2011.

[29] M. Panghal, V. Kaushal, and J. P. Yadav, "In vitro antimicrobial activity of ten medicinal plants against clinical isolates of oral cancer cases," Annals of Clinical Microbiology and Antimicrobials, vol. 10, article 21, 2011.

[30] R. V. Bagiu, B. Vlaicu, and M. Butnariu, "Chemical composition and in Vitro antifungal activity screening of the allium ursinum L. (Liliaceae)," International Journal of Molecular Sciences, vol. 13, no. 2, pp. 1426-1436, 2012.

[31] V. Kuete, "Potential of Cameroonian plants and derived products against microbial infections: A review," Planta Medica, vol. 76, no. 14, pp. 1479-1491, 2010.
[32] E. M. Costa, S. Silva, A. R. Madureira, A. Cardelle-Cobas, F. K. Tavaria, and M. M. Pintado, "A comprehensive study into the impact of a chitosan mouthwash upon oral microorganism's biofilm formation in vitro," Carbohydrate Polymers, vol. 101, no. 1, pp. 1081-1086, 2014.

[33] I. R. G. Capoci, P. de Souza Bonfim-Mendonça, and G. S. Arita, "Propolis is an efficient fungicide and inhibitor of biofilm production by vaginal Candida albicans," Evidence-Based Complementary and Alternative Medicine, vol. 2015, Article ID 287693, 9 pages, 2015.

[34] G. Malich, B. Markovic, and C. Winder, "The sensitivity and specificity of the MTS tetrazolium assay for detecting the in vitro cytotoxicity of 20 chemicals using human cell lines," Toxicology, vol. 124, no. 3, pp. 179-192, 1997.

[35] D. M. Maron and B. N. Ames, "Revised methods for the Salmonella mutagenicity test," Mutation Research, vol. 113, no. 3-4, pp. 173-215, 1983.

[36] N. Y. Kado, D. Langley, and E. Eisenstadt, "A simple modification of the Salmonella liquid-incubation assay Increased sensitivity for detecting mutagens in human urine," Mutation Research Letters, vol. 121, no. 1, pp. 25-32, 1983.

[37] S. C. Vasconcelos Filho, A. L. L. Ferreira, J. M. Vasconcelos, L. S. Silva, and L. C. S. Pereira, "Secretory structures in cochlospermum regium (schrank) pilg. (bixaceae): distribution and histochemistry," Journal of Medicinal Plants Research, vol. 8, no. 27, pp. 947-952, 2014.

[38] V. Goulas, V. Exarchou, L. Kanetis, and I. P. Gerothanassis, "Evaluation of the phytochemical content, antioxidant activity and antimicrobial properties of mountain tea (Sideritis syriaca) decoction," Journal of Functional Foods, vol. 6, no. 1, pp. 248258, 2014.

[39] M. P. Popova, I. B. Chinou, I. N. Marekov, and V. S. Bankova, "Terpenes with antimicrobial activity from Cretan propolis," Phytochemistry, vol. 70, no. 10, pp. 1262-1271, 2009.

[40] K. Y. Ho, C. C. Tsai, J. S. Huang, C. P. Chen, T. C. Lin, and C. C. Lin, "Atividade antimicrobiana de componentes de tanino de Vaccinium vitis-idaea L.," Jounalof Pharmacy and Pharmacology, vol. 53, no. 2, pp. 187-191, 2001.

[41] J. P. Dzoyem, H. Hamamoto, B. Ngameni, B. T. Ngadjui, and K. Sekimizu, "Antimicrobial action mechanism of flavonoids from dorstenia species," drug discoveries \& therapeutics, vol. 7, no. 2, pp. 66-72, 2013.

[42] T. P. Cushnie and A. J. Lamb, "Antimicrobial activity of flavonoids," International Journal of Antimicrobial Agents, vol. 26, no. 5, pp. 343-356, 2005.

[43] S. Subashchandrabose, T. H. Hazen, A. R. Brumbaugh et al., "Host-specific induction of Escherichia coli fitness genes during human urinary tract infection," Proceedings of the National Acadamy of Sciences of the United States of America, vol. 111, no. 51, pp. 18327-18332, 2014.

[44] O. E. Chinenye, U. Ebere, and A. S. Okechukwu, "Okechukwu, In vitro antibacterial activities of Cochlospermum planchonii roots crude extracts," Journal of Pharmacy and Biological Sciences, vol. 10, no. 2, pp. 115-120, 2015.

[45] M. C. Inácio, T. A. Paz, B. W. Bertoni, and A. M. S. Pereira, "Effect of environmental and phenological factors on the antimicrobial activity of Cochlospermum regium (Schrank) Pilg. roots," Acta Scientiarum - Agronomy, vol. 38, no. 4, pp. 467473, 2016.

[46] V. E. G. Rodrigues and D. A. de Carvalho, "Levantamento etnobotânico de plantas medicinais no domínio do cerrado na 
região do Alto Rio Grande - Minas Gerais," Revista Ciência Agrotecnologia, vol. 25, no. 1, pp. 102-123, 2001.

[47] A. Rezk, A. Al-Hashimi, W. John, H. Schepker, M. S. Ullrich, and K. Brix, "Assessment of cytotoxicity exerted by leaf extracts from plants of the genus Rhododendron towards epidermal keratinocytes and intestine epithelial cells," BMC Complementary and Alternative Medicine, vol. 15, no. 1, article no. 364, 2015.

[48] A. L. Cunha-Laura, R. J. Oliveira, A. L. C. de Barros, J. M. de Siqueira, M. do Carmo Vieira, and S. A. Auharek, "Maternal exposure to Cochlospermum regium: a toxicological evaluation," Revista Brasileira de Farmacognosia, vol. 23, no. 2, pp. 374-378, 2013.

[49] R. Moreira, L. Santos, S. Varella, E. Varanda, and W. Vilegas, "Avaliação da atividade mutagênica do extrato etanólico bruto de Paepalanthus latipes (Eriocaulaceae) e dos compostos flavonoídicos 7-metoxilados relacionados," Revista Brasileira de Farmacognosia, vol. 12, no. 1, 2002.

[50] W. B. Nunes and S. de Carvalho, "Evaluation of the mutagenic potential of Cochlospermum regium in Drosophila melanogaster male germ cells," Genetics and Molecular Biology, vol. 26, no. 4, pp. 545-549, 2003. 


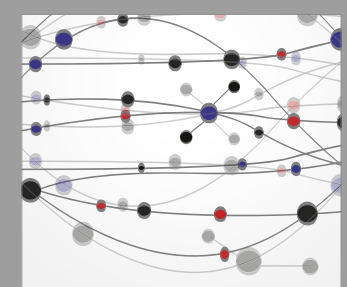

The Scientific World Journal
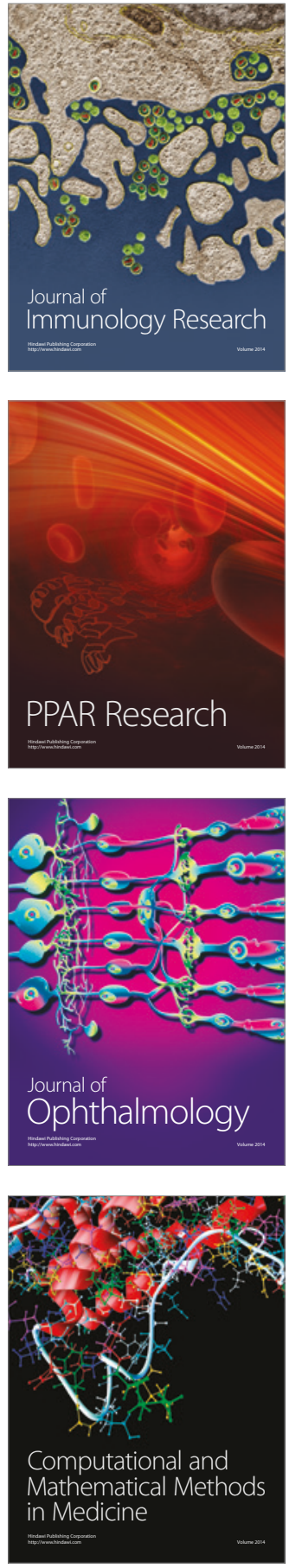

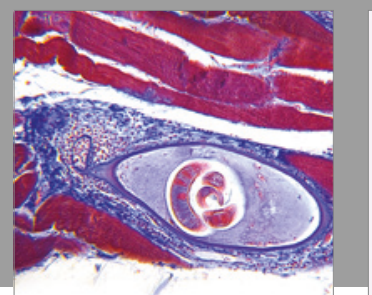

Gastroenterology Research and Practice
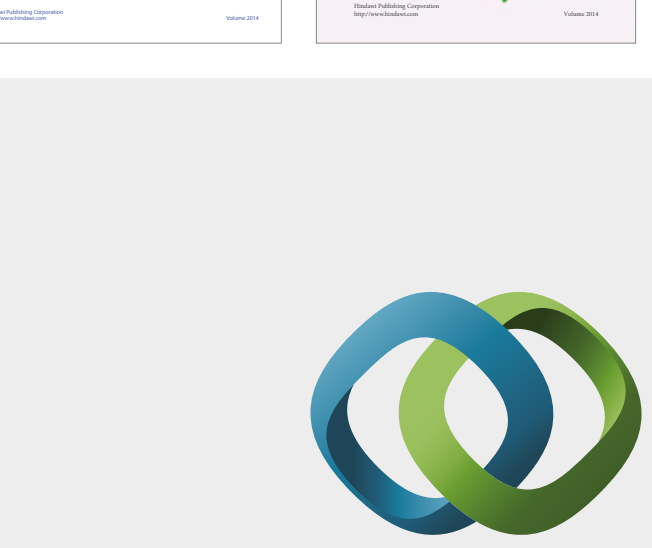

\section{Hindawi}

Submit your manuscripts at

https://www.hindawi.com
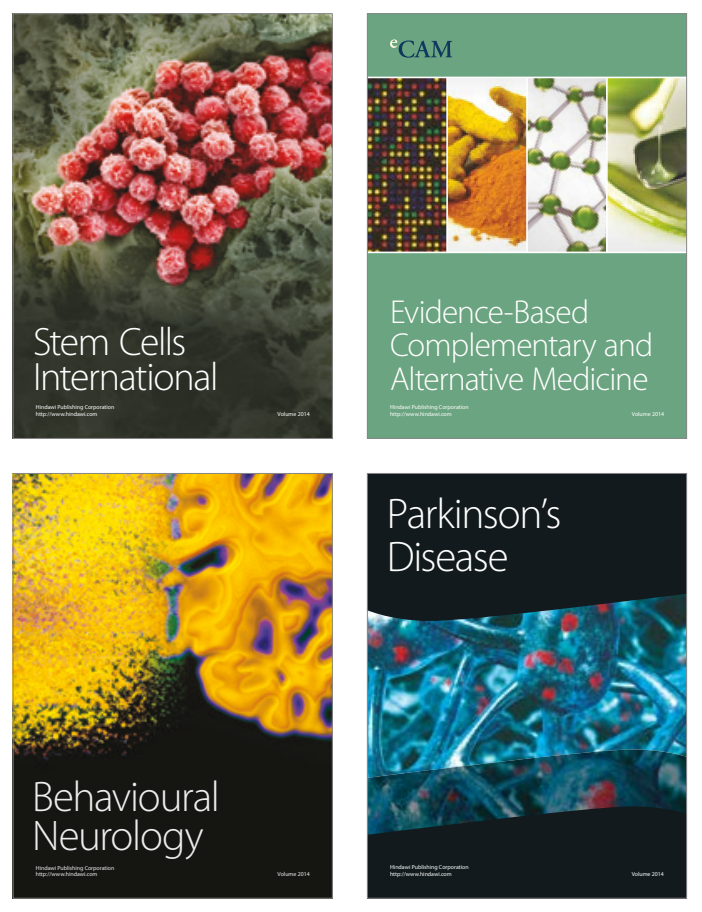
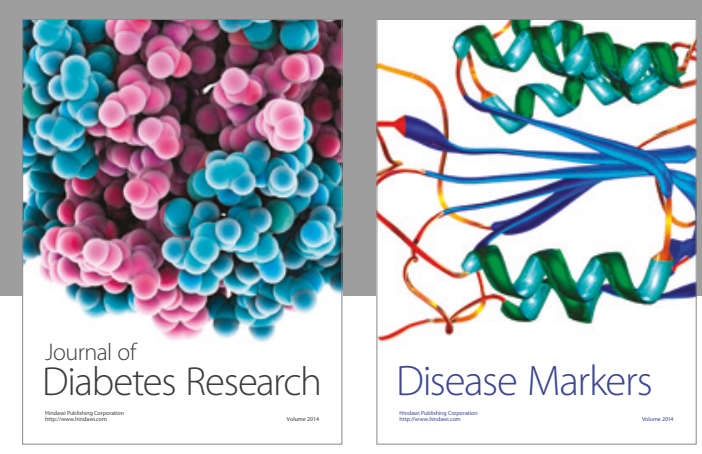

Disease Markers
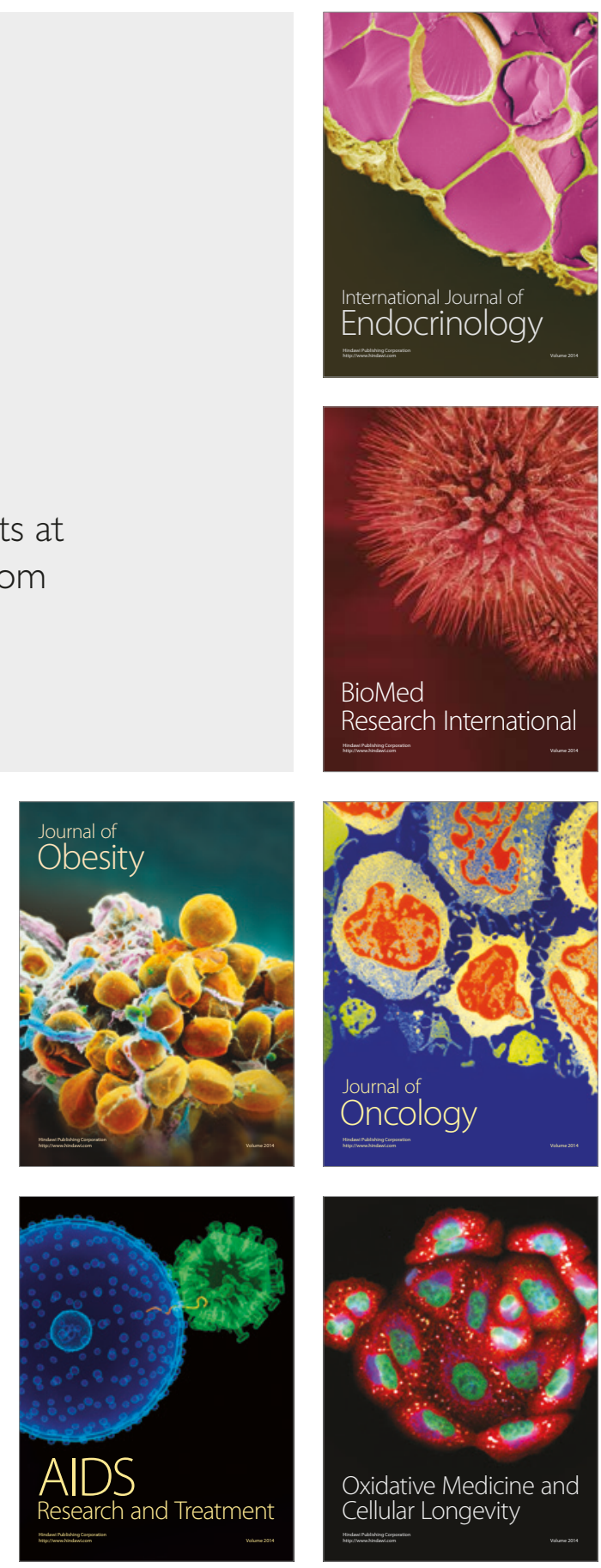